\title{
PENGARUH PEMAHAMAN KONSEP GEOMETRI TERHADAP KEMAMPUAN SISWA DALAM MENYELESAIKAN SOAL-SOAL BIDANG DATAR (Studi Kasus Kelas VII di SMP Negeri 1 Cidahu Kabupaten Kuningan)
}

\author{
Iim Rohimah, Indah Nursuprianah \\ Tadris Matematika, IAIN Syekh Nurjati Cirebon \\ Jalan perjuangan Bypass Sunyaragi
}

\begin{abstract}
ABSTRAK
Penelitian ini bertujuan untuk mengetahui; bagaimana pemahaman konsep geometri tentang segitiga dan segi empat (kedudukan dua garis, sifat-sifat garis sejajar, besar sudut, jenis sudut). Untuk mengetahui bagaimana kemampuan siswa dalam menyelesaikan soal-soal Bidang Datar (persegi, persegi panjang, segitiga, jajargenjang) tentang sifat-sifat, luas, dan keliling persegi, persegi panjang, segitiga, jajargenjang, dan penggunaannya dalam pemecahan masalah. Banyak konsep matematika lebih mudah dipahami jika disajikan dengan bahasa geometri. Untuk dapat mempelajari geometri dengan baik, siswa harus dituntut untuk menguasai kemampuan dasar geometri, keterampilan dasar dalam belajar geometri terdiri dari: kemahiran visual, lisan, melukis, logika, dan aplikasi. Pemahaman konsep geometri dalam penelitian ini yaitu paham/mengerti akan materi geometri itu sendiri, dimana materi geometri itu sendiri membahas tentang hubungan titik, garis, sudut, bidang dan benda-benda ruang serta sifatsifatnya.Pendekatan yang digunakan adalah pendekatan kuantitatif. Populasi dalam penelitian ini adalah kelas VII SMP Negeri 1 Cidahu yang terdiri dari 10 kelas dengan jumlah 402 siswa. Sedangkan pengambilan sampel menggunakan teknik purposive sampling dengan mengambil satu kelas dari 10 kelas yaitu kelas VII E yang berjumlah 37 siswa. Hasil penelitian, setelah dilakukan pegolahan data berdasarkan program bantuan SPSS versi 16 diperoleh nilai uji hipotesis menunjukkan bahwathitung sebesar 4,294. Pada derajat bebas $(\mathrm{df})=35$, nilai $t$ tabel pada taraf signifikansi 5\% adalah 2,030. Dapat disimpulkan bahwa thitung $>$ ttabel yaitu 4,294 >2,030 yang berarti bahwa $H_{o}$ ditolak dan $H_{a}$ diterima. Ini menunjukkan bahwa terdapat pengaruh pemahaman konsep geometri terhadap kemampuan siswa dalam menyelesaikan soal-soal bidang datar. Didapat korelasi antara pemahaman konsep geometri dengan kemampuan siswa dalam menyelesaikan soal-soal bidang datar (r) adalah 0,587, dan koefisien determinasi (R) sebesar 0,345.
\end{abstract}

Kata kunci: Pemahaman Konsep, Geometri, Bidang Datar, Menyelesaikan Soal-Soal Bidang Datar

\section{PENDAHULUAN}

Suatu fenomena menunjukkan bahwa masih banyak siswa yang tidak menyukai belajar matematika. Hal ini sesuai dengan pendapat Turmudi yang mengemukakan, bahwa "Bertahun-tahun telah diupayakan agar matematika dapat dikuasai siswa dengan baik oleh ahli pendidikan dan ahli pendidikan matematika. Namun, hasilnya masih menunjukkan bahwa tidak banyak siswa yang menyukai matematika dari setiap kelasnya.

Banyaknya siswa yang tidak menyukai matematika diduga disebabkan oleh kesulitan memahami matematika. Hal ini sesuai dengan pendapat Mulyono Abdurrahman yang mengemukakan, bahwa "Dari berbagai bidang studi yang diajarkan di sekolah, matematika merupakan bidang studi yang dianggap paling sulit oleh para siswa".
Kesulitan belajar matematika sering disebabkan karena terdapatnya kendala yang dialami siswa dalam memahami konsep matematika tersebut. Rendahnya kemampuan matematika siswa juga dapat dilihat dari penguasaan siswa terhadap materi. Salah satunya adalah dengan memberikan tes atau soal tentang materi tersebut kepada siswa. Kesalahan siswa dalam mengerjakan soal tersebut dapat menjadi salah satu petunjuk untuk mengetahui sejauh mana siswa menguasai materi.

Rendahnya penguasaan materi geometri pada jenjang pendidikan dasar menunjukkan ketidakberhasilan siswa dalam belajar geometri pada jenjang tersebut. Ketidakberhasilan ini disebabkan siswa mengalami kesulitan dalam memahami 
fakta, konsep dan prinsip geometri. Rendahnya penguasaan siswa terhadap materi geometri dapat disebabkan oleh faktor yang berasal dari dalam diri siswa (faktor internal) dan faktor yang berasal dari lingkungan luar siswa (faktor eksternal). Salah satu faktor internal yang mempengaruhi keberhasilan belajar geometri adalah perkembangan intelektual. Selain faktor internal, juga terdapat faktor eksternal yang dapat mempengaruhI keberhasilan belajar geometri yaitu metode mengajar guru, sarana dan prasarana yang mendukung serta lingkungan sekitar siswa yang kondusif.

Pembelajaran geometri di sekolah sebaiknya diarahkan pada penyelidikan dan pemanfaatan ide-ide serta hubungan antara sifat-sifat geometri.Dalam pembelajaran geometri siswa diharapkan bisa memvisualisasikan, menggambarkan, serta membandingkan bangun-bangun geometri dalam berbagai posisi, sehingga siswa dapat memahaminya.

\section{KAJIAN TEORI}

Hakikat belajar menurut Uno, adalah "Suatu aktifitas mental untuk memahami arti dan hubungan-hubungan serta simbol-simbol, kemudian diterapkannya dalam situasi nyata".Schoenfeld sebagaimana dikutip oleh Uno mendefinisikan, bahwa "Belajar matematika berkaitan dengan apa dan bagaimana menggunakannya dalam membuat keputusan untuk memecahkan masalah".

Menurut Uno bahwa: Belajar matematika merupakan suatu kegiatan yang berkenaan dengan penyeleksian himpunan-himpunan dari unsur matematika yang sederhana dan merupakan himpunan-himpunan baru, yang selanjutnya membentuk himpunanhimpunan baru yang lebih rumit. Demikian seterusnya, sehingga dalam belajar matematika harus dilakukan dengan hierarkis. Dengan kata lain, belajar matematika pada tahap yang lebih tinggi harus didasarkan pada tahap belajar yang lebih rendah.

Pemahaman menurut Winkel, adalah "Mencakup kemampuan untuk menangkap makna berarti dari bahan yang dipelajari”. Sedangkan menurut Uno, "Pemahaman diartikan sebagai kemampuan seseorang dalam menafsirkan atau menyatakan sesuatu dengan caranya sendiri tentang pengetahuan yang pernah diterimanya". Selanjutnya menurut Haryanto, pemahaman didefinisikan sebagai "Kemampuan untuk menangkap pengertian dan sesuatu. Hal ini dapat dipertunjukkan

Geometri adalah setiap bangun yang dipandang sebagai himpunan titik-titik tertentu (special set points), sedangkan ruang artinya sebagai himpunan semua titik". Sedangkan menurut Moeharti, "Geometri didefinisikan sebagai cabang matematika yangmempelajari titik, garis, bidang dan benda-benda ruang serta sifatsifatnya,ukuran-ukurannya dan hubungan satu sama lain

Seperti yang telah dijelaskan juga oleh Traves, dkk. yang dikutip oleh Fadjar Shadiq menyatakan bahwa: "Geometry is the study of relationships among points, lines, angels, surfaces and solids." Hal ini menunjukkan bahwa geometri adalah ilmu yang membahas tentang hubungan antara titik, garis, sudut, bidang, dan bangun-bangun ruang. Maka di bawah ini adalah pembahasan mengenai komponen-komponen dari geometri.

Banyak konsep matematika lebih mudah dipahami jika disajikan dengan bahasa geometri. Untuk dapat mempelajari geometri dengan baik, siswa harus dituntut untuk menguasai kemampuan dasar geometri, keterampilan dalam membuktikan, keterampilan dalam membuat lukisan dasar geometri dan mempunyai daya tilik ruang yang memadai.

Menurut Nana Syaodih, "Karakteristik dari kemampuan siswa adalah pengetahuan dan keterampilan-keterampilan yang relevan dalam menyelesaikan masalah yang dihadapi oleh siswa". Siswa dikatakan pandai apabila perbuatannya memenuhi kriteria yang ditentukan oleh Carl Witheington sebagaimana dikutip oleh Nana Syaodih. Adapun kriteria itu adalah sebagai berikut:

a. Memiliki kemampuan yang cepat dalam bekerja dengan bilangan

b. Efisien dalam berbahasa

c. Kemampuan dalam mengamati dan menarik kesimpulan dari hasil pengamatan yang cukup cepat

d. Kemampuan mengingat yang cukup cepat dan tahan lama

e. Kreatif dan cepat memahami hubungan

f. Memiliki daya khayal atau imajinasi yang cukup tinggi

Kemampuan siswa dalam memahami materi matematika, khususnya materi yang baru sangat dipengaruhi oleh kemampuan dasar. Makin tinggi kemampuan dasar yang 
dimiliki siswa dalam pelajaran matematika, maka semakin mudah pula untuk menerima pelajaran matematika lanjutan yang diberikan oleh gurunya. Sebaliknya, kurangnya kemampuan dasar yang dimiliki siswa akan menyebabkan sulitnya untuk menerima pelajaran matematika selanjutnya. Hal ini dapat mempengaruhi prestasi belajar siswa dalam menerapkan suatu konsep atau teorema tertentu. Oleh karena itu keberhasilan seseorang dalam mempelajari salah satu pokok bahasan matematika sangat dipengaruhi oleh pemahaman dasar yang menjadi materi prasyarat dari materi yang akan dipelajari.

\section{METODOLOGI PENELITIAN}

Penelitian ini dilaksanakan di SMP Negeri 1 Cidahu Kabupaten Kuningan Tahun Ajaran 2012/2013, yang berada di Jalan Raya Kuningan - Ciledug KM.21 Kecamatan Cidahu Kabupaten Kuningan. Waktu penelitian dimulai mei hingga agustus tahun 2013.

Metode yang digunakan dalam penelitian ini adalah pendekatan kuantitatif dikarenakan data hasil penelitian akan dianalisis secara statistik. Penelitian ini bersifat studi kasus, yaitu tentang pengaruh pemahaman konsep geometri terhadap kemampuan siswa dalam menyelesaikan soal-soal bidang datar di kelas VII SMP Negeri 1 Cidahu.

Penelitian yang berjudul "Pengaruh Pemahaman Konsep Geometri Terhadap Kemampuan Siswa dalam Menyelesaikan Soal-soal Bidang Datar" ini menggunakan desain "One Shot Case Study"model. "One Shot Case Study"yaitu model pendekatan yang menggunakan satu kali pengumpulan data "suatu saat". Dengan pola sebagai berikut:

\section{O}

Keterangan :

$\mathrm{X}=$ Treatment yang diberikan (variabel independen)

$\mathrm{O}=$ Hasil observasi sesudah treatment (variabel dependen)

Populasi target adalah seluruh siswa-siswi SMP Negeri 1 Cidahu, sedangkan populasi HASIL DAN PEMBAHASAN terjangkau dalam penelitian ini yaitu populasi seluruh kelas VII yang berjumlah 402 siswa yang terbagi menjadi 10 kelas. Peneliti mengambil subyek sampel sebanyak 1 kelas dari 10 kelas dengan menggunakan teknik purposive sampling yaitu teknik penentuan sampel dengan pertimbangan tertentu. Pertimbangan tersebut didasarkan kepada Guru Matematika SMP Negeri 1 Cidahu yang sudah berpengalaman dalam mengajar. Beliau memberikan pertimbangan untuk mengambil sampel berdasarkan kriteria tertentu, yakni materi yang disampaikan sudah selesai/sampai segitiga dan segi empat dibandingkan dengan kelas VII yang lain. Jadi, sampel yang dipilih dalam penelitian di kelas VII SMP Negeri 1 Cidahu adalah kelas VII E yang berjumlah 37 siswa.

Teknik pengumpulan data penelitian pada variabel pemahaman konsep geometri adalah tes matematika pada pokok bahasan bidang datar. Sedangkan data pada variabel kemampuan siswa dalam menyelesaikan soal-soal bidang datar diperoleh dari pengerjaan soal matematika.

Teknik analisis data dalam penelitian ini melalui berbagai tahapan diantaranya;
a. Penskoran
b. Persentase pencapaian indikator
c. Uji normalitas
d. Uji homogenitas
e. Uji hipotesis (uji regresi)

Hipotesis statistik dalam penelitian tentang "Pengaruh Pemahaman Konsep Geometri Terhadap Kemampuan Siswa dalam Menyelesaikan Soal-soal Bidang Datar (Studi Kasus Kelas VII di SMP Negeri 1 Cidahu Kabupaten Kuningan)". Maka hipotesis statistiknya adalah sebagai berikut:

$H_{o}: \beta_{0}=0$; (tidak ada pengaruh
pemahaman konsep geometri
terhadapkemampuan siswa dalam
menyelesaikan soal-soal bidang
datar)
$H_{a}: \beta_{0}>0$;(ada pengaruh positif
yang signifikan pemahaman konsep
geometri terhadapkemampuan siswa
dalam menyelesaikan soal-soal
bidang datar).

Deskripsi data hasil tes pemahaman konsep geometridiperoleh keterangan sebagai berikut: 
Tabel 1

Descriptive Statistics

\begin{tabular}{|l|c|c|c|c|c|c|}
\hline & N & Minimum & Maximum & Sum & Mean & $\begin{array}{c}\text { Std. } \\
\text { Deviatio } \\
\mathrm{n}\end{array}$ \\
\hline $\begin{array}{l}\text { Pemahaman } \\
\text { Konsep Geometri }\end{array}$ & 37 & 44.0 & 96.0 & 2393.0 & 64.676 & 16.2259 \\
\hline Valid N (listwise) & 37 & & & & & \\
\hline
\end{tabular}

Berdasarkan tabel 1,jumlah responden sebanyak 37 siswa. Setelah tes pilihan ganda beralasan tentang pemahaman konsep geometri disebarkan kepada siswa, maka didapat skor mean sebesar 64,676 yang artinya pemahaman konsep geometri secara keseluruhan memiliki rata-rata sebesar 64,676. Standar deviasi (simpangan baku) didapat sebesar 16,2259. Nilai minimum yang didapat menunjukkan angka sebesar
44,0 yang artinya pemahaman konsep geometri yang terkecil secara keseluruhan adalah sebesar 44,0.Pemahaman konsep geometri yang terbesar secara keseluruhan menunjukan nilai maksimum sebesar 96,0, sedangkan jumlah total nilai sebesar 2393,0.Artinya rata-rata skor pada pemahaman konsep geometri termasuk ke dalam kriteriasedang karena berada pada rentang $61-70$.

Adapun jawaban yang diperoleh dari keterampilan visual tercantum dalam tabel di bawah ini:

Tabel 2

Deskripsi Data Keterampilan Visual

\begin{tabular}{|c|c|c|c|c|c|c|}
\hline Indikator & $\begin{array}{c}\text { No. } \\
\text { Ite } \\
\mathrm{m}\end{array}$ & $\begin{array}{c}\text { Sko } \\
\mathrm{r}\end{array}$ & $\mathrm{F}$ & $\mathrm{N}$ & $\begin{array}{c}P \\
=\frac{F}{N} \times 100 \%\end{array}$ & Interpretasi \\
\hline $\begin{array}{l}>\text { Mengenal } \\
\text { macam- } \\
\text { macam } \\
\text { bangun datar } \\
>\text { Mengamati } \\
\text { bagian } \\
\text { bangun datar } \\
>\text { Mengklasifika } \\
\text { sikan bangun } \\
\text { datar } \\
\text { menurut } \\
\text { sifatnya }\end{array}$ & 1 & $\begin{array}{l}1 \\
2 \\
1 \\
2 \\
1 \\
2\end{array}$ & $\begin{array}{l}7 \\
3 \\
0\end{array}$ & $\begin{array}{l}3 \\
7 \\
3 \\
7\end{array}$ & $\begin{array}{c}43,2 \\
56,8 \\
29,7 \\
70,3 \\
\\
18,9 \\
81,1\end{array}$ & $\begin{array}{c}\text { Hampir } \\
\text { setengahnya } \\
\text { Sebagian } \\
\text { besar } \\
\text { Hampir } \\
\text { setengahnya } \\
\text { Sebagian } \\
\text { besar } \\
\text { Sebagian } \\
\text { kecil } \\
\text { Hampir } \\
\text { seluruhnya }\end{array}$ \\
\hline Indikator & $\begin{array}{c}\text { No. } \\
\text { Ite } \\
\mathrm{m}\end{array}$ & $\begin{array}{c}\text { Sko } \\
\text { r }\end{array}$ & $\mathrm{F}$ & $\mathrm{N}$ & $\begin{array}{c}P \\
=\frac{F}{N} \times 100 \%\end{array}$ & Interpretasi \\
\hline $\begin{array}{l}\text { Mengumpulk } \\
\text { an informasi } \\
\text { berdasarkan } \\
\text { visual }\end{array}$ & 4 & $\begin{array}{l}1 \\
2\end{array}$ & $\begin{array}{l}2 \\
2 \\
1 \\
5 \\
\end{array}$ & $\begin{array}{l}3 \\
7 \\
3 \\
7 \\
\end{array}$ & $\begin{array}{l}59,5 \\
40,5\end{array}$ & $\begin{array}{l}\text { Sebagian } \\
\text { besar } \\
\text { Hampir } \\
\text { setengahnya }\end{array}$ \\
\hline
\end{tabular}




\begin{tabular}{|c|c|c|c|c|c|c|}
\hline $\begin{array}{l}\text { Mempresenta } \\
\text { sikan } \\
\text { representasi } \\
\text { model }\end{array}$ & 5 & 1 & $\begin{array}{l}1 \\
6\end{array}$ & $\begin{array}{l}3 \\
7 \\
3 \\
7\end{array}$ & $\begin{array}{l}43,2 \\
56,7\end{array}$ & $\begin{array}{c}\text { Hampir } \\
\text { setengahnya } \\
\text { Sebagian } \\
\text { besar }\end{array}$ \\
\hline
\end{tabular}

Adapun jawaban yang diperoleh dari keterampilan verbal tercantum dalam tabel di bawah ini:

Tabel 3

Deskripsi Data Keterampilan verbal

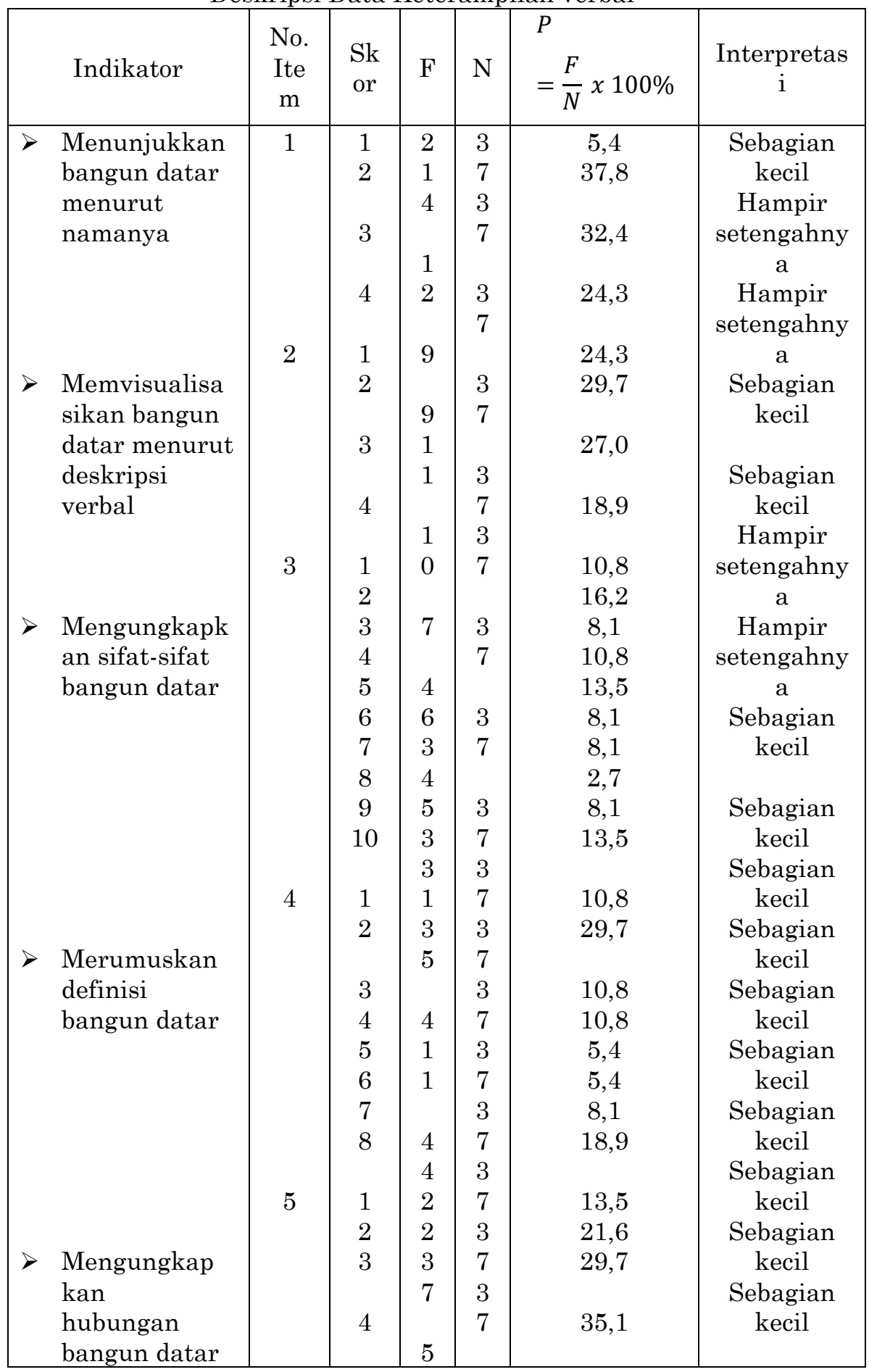


ISSN $2086-3918$

\begin{tabular}{|c|c|c|c|c|c|c|}
\hline Indikator & $\begin{array}{c}\text { No. } \\
\text { Ite } \\
\mathrm{m}\end{array}$ & $\begin{array}{l}\text { Sk } \\
\text { or }\end{array}$ & $\mathrm{F}$ & $\mathrm{N}$ & $\begin{array}{l}P \\
=\frac{F}{N} \times 100 \%\end{array}$ & $\underset{\mathrm{i}}{\text { Interpretas }}$ \\
\hline & & & $\begin{array}{l}8 \\
1 \\
1 \\
1 \\
3\end{array}$ & $\begin{array}{l}3 \\
7 \\
3 \\
7 \\
3 \\
7 \\
3 \\
7 \\
3 \\
7 \\
3 \\
7 \\
3 \\
7 \\
3 \\
7 \\
3 \\
7 \\
3 \\
7 \\
3 \\
7 \\
3 \\
7\end{array}$ & & $\begin{array}{c}\text { Sebagian } \\
\text { kecil } \\
\text { Sebagian } \\
\text { kecil } \\
\text { Hampir } \\
\text { setengahny } \\
\text { a } \\
\text { Sebagian } \\
\text { kecil } \\
\text { Sebagian } \\
\text { kecil } \\
\text { Sebagian } \\
\text { kecil } \\
\text { Sebagian } \\
\text { kecil } \\
\text { Sebagian } \\
\text { kecil } \\
\text { Sebagian } \\
\text { kecil } \\
\\
\text { Sebagian } \\
\text { kecil } \\
\text { Sebagian } \\
\text { kecil } \\
\text { Hampir } \\
\text { setengahny } \\
\text { a } \\
\text { Hampir } \\
\text { setengahny } \\
\text { a }\end{array}$ \\
\hline
\end{tabular}

Adapun jawaban yang diperoleh dari keterampilan menggambar tercantum dalam tabel di bawah ini:

Tabel 4

Deskripsi Data Keterampilan menggambar

\begin{tabular}{|c|c|c|c|c|c|c|}
\hline Indikator & $\begin{array}{l}\text { No. } \\
\text { Item }\end{array}$ & Skor & $\mathrm{F}$ & $\mathrm{N}$ & $\begin{array}{l}P \\
=\frac{F}{N} \times 100 \%\end{array}$ & Interpretasi \\
\hline $\begin{array}{l}\text { Mensketsa } \\
\text { gambar } \\
\text { menurut } \\
\text { definisi verbal }\end{array}$ & 3 & $\begin{array}{l}1 \\
2 \\
3 \\
\\
1 \\
2 \\
\\
3 \\
4 \\
5 \\
1 \\
\\
\\
2\end{array}$ & $\begin{array}{c}3 \\
6 \\
28\end{array}$ & $\begin{array}{l}37 \\
37 \\
37 \\
37 \\
37\end{array}$ & $\begin{array}{c}8,1 \\
16,2 \\
75,7 \\
\\
\\
5,4 \\
29,7 \\
\\
\\
10,8 \\
18,9 \\
35,1 \\
\\
29,7 \\
\\
\\
18,9\end{array}$ & $\begin{array}{c}\text { Sebagian } \\
\text { kecil } \\
\text { Sebagian } \\
\text { kecil } \\
\text { Sebagian } \\
\text { besar } \\
\\
\\
\text { Sebagian } \\
\text { kecil } \\
\text { Hampir } \\
\text { setengahnya } \\
\text { Sebagian } \\
\text { kecil }\end{array}$ \\
\hline
\end{tabular}


ISSN 2086 - 3918

\begin{tabular}{|c|c|c|c|c|c|c|}
\hline Indikator & $\begin{array}{l}\text { No. } \\
\text { Item }\end{array}$ & Skor & $\mathrm{F}$ & $\mathrm{N}$ & $\begin{array}{l}P \\
=\frac{F}{N} \times 100 \%\end{array}$ & Interpretasi \\
\hline $\begin{array}{l}\text { Menggambar } \\
\text { bangun } \\
\text { berdasar sifat } \\
\text { bangun datar }\end{array}$ & & 3 & 9 & 37 & 51,4 & $\begin{array}{l}\text { Sebagian } \\
\text { kecil } \\
\text { Sebagian } \\
\text { kecil } \\
\text { Hampir } \\
\text { seteng } 64 \\
\text { Seba } \\
\text { keuı } \\
\text { Sebagian } \\
\text { besar }\end{array}$ \\
\hline Indikator & $\begin{array}{l}\text { No. } \\
\text { Item }\end{array}$ & Skor & $\mathrm{F}$ & $\mathrm{N}$ & $\begin{array}{l}P \\
=\frac{F}{N} \times 100 \%\end{array}$ & Interpretasi \\
\hline $\begin{array}{l}\text { Mengkonstruksi } \\
\text { gambar bangun } \\
\text { datar dengan } \\
\text { gambar yang } \\
\text { diberikan } \\
\\
\\
\text { Mengkonstruksi } \\
\text { model geometri } \\
\text { dan } \\
\text { penyangkalnya }\end{array}$ & 4 & $\begin{array}{l}1 \\
2 \\
3 \\
4 \\
4 \\
5 \\
1 \\
2\end{array}$ & $\begin{array}{c}7 \\
5 \\
11 \\
6 \\
8 \\
17 \\
20\end{array}$ & $\begin{array}{l}37 \\
37 \\
37 \\
\\
37 \\
37 \\
\\
37 \\
\\
\\
37\end{array}$ & $\begin{array}{l}18,9 \\
13,5 \\
29,7 \\
16,2 \\
21,6 \\
45,9 \\
54,1\end{array}$ & $\begin{array}{c}\text { Sebagian } \\
\text { kecil } \\
\text { Sebagian } \\
\text { kecil } \\
\text { Hampir } \\
\text { setengahnya } \\
\text { Sebagian } \\
\text { kecil } \\
\text { Sebagian } \\
\text { kecil } \\
\\
\text { Hampir } \\
\text { setengahnya } \\
\text { Sebagian } \\
\text { besar }\end{array}$ \\
\hline
\end{tabular}

Adapun jawaban yang diperoleh dari keterampilan logika tercantum dalam tabel di bawah ini:

Tabel 5

Data Deskripsi Keretampilan Logika

\begin{tabular}{|c|c|c|c|c|c|c|}
\hline Indikator & $\begin{array}{l}\text { No. } \\
\text { Item }\end{array}$ & Skor & $\mathrm{F}$ & $\mathrm{N}$ & $\begin{array}{l}P \\
=\frac{F}{N} \times 100 \%\end{array}$ & Interpretasi \\
\hline $\begin{array}{l}\text { Mengenal } \\
\text { perbedaan dan } \\
\text { persamaan bangun } \\
\text { datar }\end{array}$ & 1 & $\begin{array}{l}1 \\
2 \\
\\
3 \\
4 \\
5 \\
\\
1 \\
2 \\
\\
3 \\
4 \\
\\
5 \\
7 \\
8\end{array}$ & $\begin{array}{c}9 \\
11 \\
7 \\
4 \\
6 \\
\\
5 \\
12 \\
\\
3 \\
6\end{array}$ & $\begin{array}{l}37 \\
37 \\
37 \\
37 \\
37 \\
37 \\
37 \\
37 \\
37\end{array}$ & $\begin{array}{c}24,3 \\
29,7 \\
\\
18,9 \\
10,8 \\
16,2 \\
\\
13.5 \\
32.4 \\
\\
8.1 \\
16.2 \\
\\
8.1 \\
5.4 \\
2.7\end{array}$ & $\begin{array}{c}\text { Sebagian } \\
\text { kecil } \\
\text { Hampir } \\
\text { setengahnya } \\
\text { Sebagian } \\
\text { kecil } \\
\text { Sebagian } \\
\text { kecil } \\
\text { Sebagian } \\
\text { kecil } \\
\text { Sebagian } \\
\text { kecil } \\
\text { Hampir } \\
\text { setengahnya }\end{array}$ \\
\hline
\end{tabular}




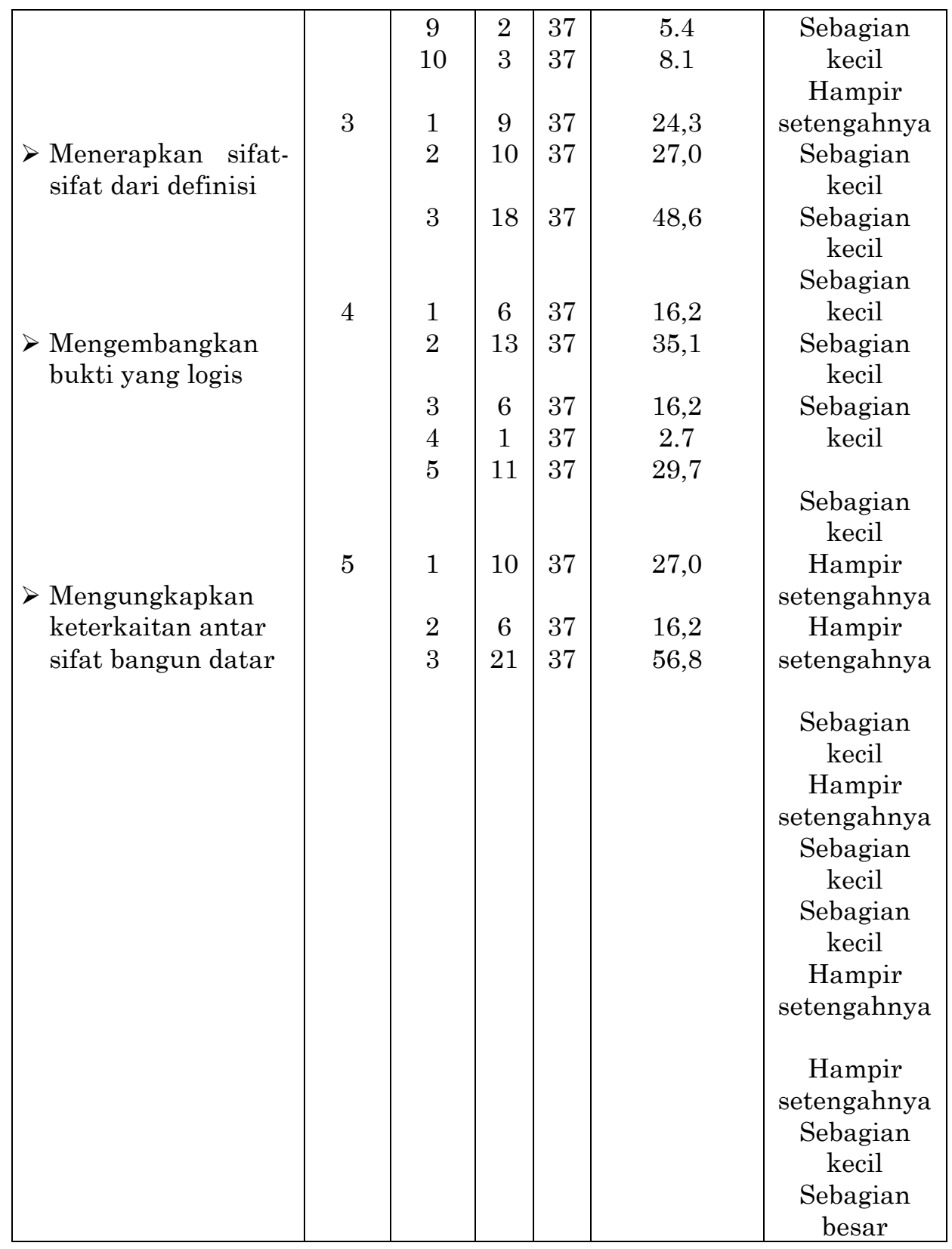

Adapun jawaban yang diperoleh dari keterampilan terapan tercantum dalam tabel di bawah ini:

Tabel 6

Deskripsi Data Keterampilan terapan

\begin{tabular}{|c|c|c|c|c|c|c|}
\hline Indikator & $\begin{array}{l}\text { No. } \\
\text { Item }\end{array}$ & Skor & $\mathrm{F}$ & $\mathrm{N}$ & $\begin{array}{l}P \\
=\frac{F}{N} \times 100 \%\end{array}$ & Interpretasi \\
\hline $\begin{array}{l}>\text { Mengenal model } \\
\text { fisik }\end{array}$ & 1 & $\begin{array}{l}2 \\
3 \\
4 \\
5 \\
\\
\\
1 \\
2\end{array}$ & $\begin{array}{c}10 \\
\\
11 \\
\\
4 \\
12\end{array}$ & $\begin{array}{l}37 \\
37\end{array}$ & $\begin{array}{l}27,0 \\
29,7 \\
10,8 \\
32,4 \\
\\
\\
21,6 \\
78,4\end{array}$ & $\begin{array}{c}\text { Hampir } \\
\text { setengahnya } \\
\text { Hampir } \\
\text { setengahnya } \\
\text { Sebagian } \\
\text { kecil } \\
\text { Hampir } \\
\text { setengahnya } \\
\text { Sebagian } \\
\text { kecil }\end{array}$ \\
\hline
\end{tabular}


ISSN $2086-3918$

\begin{tabular}{|c|c|c|c|c|c|c|}
\hline $\begin{array}{l}\text { Mensketsa } \\
\text { model berdasar } \\
\text { objek fisiknya } \\
\\
\text { Menerapkan } \\
\text { sifat-sifat model } \\
\text { geometri }\end{array}$ & 3 & $\begin{array}{l}1 \\
2 \\
3\end{array}$ & $\begin{array}{l}12 \\
10 \\
15\end{array}$ & $\begin{array}{l}37 \\
37 \\
37\end{array}$ & $\begin{array}{l}32,4 \\
27,0 \\
40,5\end{array}$ & $\begin{array}{c}\text { Hampir } \\
\text { seluruhnya } \\
\\
\text { Hampir } \\
\text { setengahnya } \\
\text { Hampir } \\
\text { setengahnya } \\
\text { Hal } \cdot 67 \\
\text { seten } 67\end{array}$ \\
\hline Indikator & $\begin{array}{l}\text { No. } \\
\text { Item }\end{array}$ & Skor & $\mathrm{F}$ & $\mathrm{N}$ & $\begin{array}{l}P \\
=\frac{F}{N} \times 100 \%\end{array}$ & Interpretasi \\
\hline $\begin{array}{l}\text { Mengembangkan } \\
\text { himpunan } \\
\text { model-model } \\
\text { bangun datar } \\
\\
\\
\text { Menerapkan } \\
\text { model geometri } \\
\text { dalam } \\
\text { pemecahan } \\
\text { masalah }\end{array}$ & 4 & $\begin{array}{l}1 \\
2 \\
3\end{array}$ & $\begin{array}{l}10 \\
17 \\
10\end{array}$ & $\begin{array}{l}37 \\
37 \\
37\end{array}$ & $\begin{array}{l}27,0 \\
45,9 \\
27,0\end{array}$ & $\begin{array}{c}\text { Sebagian } \\
\text { kecil } \\
\text { Sebagian } \\
\text { kecil } \\
\text { Hampir } \\
\text { seluruhnya } \\
\\
\text { Hampir } \\
\text { setengahnya } \\
\text { Hampir } \\
\text { setengahnya } \\
\text { Hampir } \\
\text { setengahnya }\end{array}$ \\
\hline
\end{tabular}

Deskripsi data hasil tes pilihan ganda beralasan Kemampuan Siswa dalam Menyelesaikan Soalsoal Bidang Datar diperoleh keterangan sebagai berikut:

Tabel 7

Descriptive Statistics Kemampuan Siswa Menyelesaikan Soal Bidang Datar

\begin{tabular}{|l|c|c|c|c|c|c|}
\hline & N & Minimum & Maximum & Sum & Mean & $\begin{array}{c}\text { Std. } \\
\text { Deviation }\end{array}$ \\
\hline $\begin{array}{l}\text { Kemampuan } \\
\begin{array}{l}\text { Siswa dalam } \\
\text { Menyelesaikan } \\
\text { Soal-soal Bidang } \\
\text { Datar }\end{array}\end{array}$ & 37 & 28.3 & 98.3 & $\begin{array}{c}2493 . \\
0\end{array}$ & 67.378 & 16.9061 \\
\hline Valid N (listwise) & 37 & & & & & \\
\hline
\end{tabular}

Berdasarkan tabel 6, jumlah responden sebanyak 37 siswa. Setelah tes pilihan ganda beralasan tentang Kemampuan Siswa Dalam Menyelesaikan Soal-soal Bidang Datar disebarkan kepada siswa, maka didapat skor mean sebesar 67,378 yang artinya Kemampuan Siswa Dalam Menyelesaikan Soal-soal Bidang Datar secara keseluruhan memiliki rata-rata sebesar 67,378. Standar deviasi (simpangan baku) didapat sebesar
16,9061 yang artinya menunjukan selisih simpangan antar skor dan data tersebut semakin dekat dengan sifat homogenitas. Nilai minimum yang didapat menunjukan angka sebesar 28,3 yang artinya Kemampuan Siswa Dalam Menyelesaikan Soal-soal Bidang Datar yang terkecil secara keseluruhan adalah sebesar 28,3. Kemampuan Siswa Dalam Menyelesaikan Soal-soal Bidang Datar yang terbesar secara 
keseluruhan menunjukkan nilai maksimum sebesar 98,3, sedangkan jumlah total nilai sebesar 2493,0. Artinya rata-rata skor pada kemamuan siswa dalam menyelesaikan soalsoal bidang datar termasuk kategori sedang karena pada rentang 61-70.

Tabel 8

Deskripsi Data Kemampuan Siswa Dalam Menyelesaikan Soal-Soal Bidang Datar

\begin{tabular}{|c|c|c|c|c|c|c|}
\hline Indikator & $\begin{array}{c}\text { No. } \\
\text { Ite } \\
\mathrm{m}\end{array}$ & $\begin{array}{l}\text { Sk } \\
\text { or }\end{array}$ & $\mathrm{F}$ & $\mathrm{N}$ & $\begin{aligned} & P \\
= & \frac{F}{N} \times 100\end{aligned}$ & $\begin{array}{c}\text { Interpret } \\
\text { asi }\end{array}$ \\
\hline \multirow[t]{3}{*}{$\begin{array}{l}\text { Siswadapatmengerjakanperhitunga } \\
\text { n yang } \\
\text { berkaitandengankelilingdanluasseg } \\
\text { itiga }\end{array}$} & 1 & $\begin{array}{l}1 \\
3 \\
4 \\
5\end{array}$ & $\begin{array}{l}4 \\
2 \\
4 \\
2 \\
7\end{array}$ & $\begin{array}{l}3 \\
7 \\
3 \\
7 \\
3 \\
7 \\
3 \\
7 \\
\end{array}$ & $\begin{array}{c}10,8 \\
5,4 \\
10,8 \\
73,0\end{array}$ & $\begin{array}{l}\text { Sebagian } \\
\text { kecil } \\
\text { Sebagian } \\
\text { kecil } \\
\text { Sebagian } \\
\text { kecil } \\
\text { Sebagian } \\
\text { besar }\end{array}$ \\
\hline & 2 & $\begin{array}{l}0 \\
1 \\
2 \\
3 \\
4 \\
5\end{array}$ & $\begin{array}{l}5 \\
8 \\
2 \\
3 \\
3 \\
1 \\
6\end{array}$ & $\begin{array}{l}3 \\
7 \\
3 \\
7 \\
3 \\
7 \\
3 \\
7 \\
3 \\
7 \\
3 \\
7\end{array}$ & $\begin{array}{c}13,5 \\
21,6 \\
5,4 \\
8,1 \\
8,1 \\
43,2\end{array}$ & $\begin{array}{l}\text { Sebagian } \\
\text { kecil } \\
\text { Sebagian } \\
\text { kecil } \\
\text { Sebagian } \\
\text { kecil } \\
\text { Sebagian } \\
\text { kecil } \\
\text { Sebagian } \\
\text { kecil } \\
\text { Hampir } \\
\text { setengah } \\
\text { nya }\end{array}$ \\
\hline & 3 & $\begin{array}{l}0 \\
1 \\
2 \\
3 \\
4 \\
5\end{array}$ & $\begin{array}{l}6 \\
8 \\
1 \\
5 \\
1 \\
5\end{array}$ & $\begin{array}{l}3 \\
7 \\
3 \\
7 \\
3 \\
7 \\
3 \\
7 \\
3 \\
7 \\
3 \\
7\end{array}$ & $\begin{array}{c}16,2 \\
21,6 \\
2,7 \\
13,5 \\
2,7 \\
13,5\end{array}$ & $\begin{array}{l}\text { Sebagian } \\
\text { kecil } \\
\text { Sebagian } \\
\text { kecil } \\
\text { Sebagian } \\
\text { kecil } \\
\text { Sebagian } \\
\text { kecil } \\
\text { Sebagian } \\
\text { kecil } \\
\text { Sebagian } \\
\text { kecil }\end{array}$ \\
\hline Indikator & $\begin{array}{c}\text { No. } \\
\text { Ite } \\
\mathrm{m}\end{array}$ & $\begin{array}{l}\text { Sk } \\
\text { or }\end{array}$ & $\mathrm{F}$ & $\mathrm{N}$ & $\begin{aligned} & P \\
= & \frac{F}{N} \times 100\end{aligned}$ & $\begin{array}{c}\text { Interpret } \\
\text { asi }\end{array}$ \\
\hline$>$ & & $\begin{array}{l}6 \\
7 \\
8\end{array}$ & $\begin{array}{l}2 \\
1 \\
8\end{array}$ & $\begin{array}{l}3 \\
7 \\
3 \\
7 \\
3 \\
7\end{array}$ & $\begin{array}{c}5,41 \\
2,7 \\
21,6\end{array}$ & $\begin{array}{c}\text { Sebagian } \\
\text { kecil } \\
\text { Sebagian } \\
\text { kecil } \\
\text { Sebagian } \\
\text { kecil }\end{array}$ \\
\hline $\begin{array}{l}\text { Siswadapatmengerjakanperhitung } \\
\text { yang } \\
\text { berkaitandengankelilingdanluasper } \\
\text { segipanjang }\end{array}$ & 4 & $\begin{array}{l}0 \\
1 \\
3 \\
4 \\
5\end{array}$ & $\begin{array}{l}3 \\
6 \\
2 \\
5 \\
8\end{array}$ & $\begin{array}{l}3 \\
7 \\
3 \\
7\end{array}$ & $\begin{array}{c}8,1 \\
16,2 \\
5,4 \\
13,5 \\
21,6 \\
\end{array}$ & $\begin{array}{l}\text { Sebagian } \\
\text { kecil } \\
\text { Sebagian } \\
\text { kecil }\end{array}$ \\
\hline
\end{tabular}


EduMa Vol. 5 No. 1 Juli 2016

ISSN 2086 - 3918

\begin{tabular}{|c|c|c|c|c|c|c|}
\hline \multirow[t]{3}{*}{ Indikator } & $\begin{array}{c}\text { No. } \\
\text { Ite } \\
\text { m }\end{array}$ & $\begin{array}{l}\text { Sk } \\
\text { or }\end{array}$ & $\mathrm{F}$ & $\mathrm{N}$ & $\begin{aligned} & P \\
= & \frac{F}{N} \times 100\end{aligned}$ & $\begin{array}{c}\text { Interpret } \\
\text { asi }\end{array}$ \\
\hline & & 6 & $\begin{array}{l}1 \\
3\end{array}$ & $\begin{array}{l}3 \\
7 \\
3 \\
7 \\
3 \\
7 \\
3 \\
7\end{array}$ & 35,1 & $\begin{array}{c}\text { Sebagian } \\
\text { kecil } \\
\text { Sebagian } \\
\text { kecil } \\
\text { Sebagian } \\
\text { kecil } \\
\text { Sebagian } \\
\text { kecil }\end{array}$ \\
\hline & 5 & $\begin{array}{l}0 \\
1 \\
2 \\
4 \\
5 \\
6 \\
7 \\
8\end{array}$ & $\begin{array}{l}1 \\
1 \\
3 \\
3 \\
3 \\
2 \\
3 \\
4 \\
8\end{array}$ & $\begin{array}{l}3 \\
7 \\
3 \\
7 \\
3 \\
7 \\
3 \\
7 \\
3 \\
7 \\
3 \\
7 \\
3 \\
7 \\
3 \\
7 \\
\end{array}$ & $\begin{array}{c}2,7 \\
35,1 \\
8,1 \\
8,1 \\
5,4 \\
8,1 \\
10,8 \\
21,6\end{array}$ & $\begin{array}{c}\text { Sebagian } \\
\text { kecil } \\
\text { Sebagian } \\
\text { kecil } \\
\text { Sebagian } \\
\text { kecil } \\
\text { Sebagian } \\
\text { kecil } \\
\text { Sebagian } \\
\text { kecil } \\
\text { Sebagian } \\
\text { kecil } \\
\text { Sebagian } \\
\text { kecil } \\
\text { Sebagian } \\
\text { kecil }\end{array}$ \\
\hline \multirow[t]{3}{*}{$\begin{array}{l}\text { Siswadapatmengerjakanperhitung } \\
\text { yang } \\
\text { berkaitandengankelilingdanluasper } \\
\text { segi }\end{array}$} & 6 & $\begin{array}{l}0 \\
1 \\
3 \\
4 \\
5\end{array}$ & $\begin{array}{l}1 \\
2 \\
3 \\
1 \\
3 \\
0\end{array}$ & $\begin{array}{l}3 \\
7 \\
3 \\
7 \\
3 \\
7 \\
3 \\
7 \\
3 \\
7\end{array}$ & $\begin{array}{c}2,7 \\
5,4 \\
8,1 \\
2,7 \\
81,1\end{array}$ & $\begin{array}{c}\text { Sebagian } \\
\text { kecil } \\
\text { Sebagian } \\
\text { kecil } \\
\text { Sebagian } \\
\text { kecil } \\
\text { Sebagian } \\
\text { kecil } \\
\text { Hampir } \\
\text { seluruhn } \\
\text { ya }\end{array}$ \\
\hline & 7 & $\begin{array}{l}1 \\
3 \\
4 \\
5\end{array}$ & $\begin{array}{l}5 \\
5 \\
7 \\
2 \\
0\end{array}$ & $\begin{array}{l}3 \\
7 \\
3 \\
7 \\
3 \\
7 \\
3 \\
7 \\
\end{array}$ & $\begin{array}{l}13,5 \\
13,5 \\
18,9 \\
54,1\end{array}$ & $\begin{array}{c}\text { Sebagian } \\
\text { kecil } \\
\text { Sebagian } \\
\text { kecil } \\
\text { Sebagian } \\
\text { kecil } \\
\text { Sebagian } \\
\text { besar } \\
\end{array}$ \\
\hline & 8 & $\begin{array}{l}0 \\
1 \\
2 \\
3 \\
4 \\
5 \\
6\end{array}$ & $\begin{array}{l}3 \\
5 \\
1 \\
3 \\
4 \\
4 \\
1 \\
7\end{array}$ & $\begin{array}{l}3 \\
7 \\
3 \\
7 \\
3 \\
7 \\
3 \\
7 \\
3 \\
7 \\
3 \\
7\end{array}$ & $\begin{array}{c}8,1 \\
13,5 \\
2,7 \\
8,1 \\
10,8 \\
10,8 \\
45,9\end{array}$ & $\begin{array}{l}\text { Sebagian } \\
\text { kecil } \\
\text { Sebagian } \\
\text { kecil } \\
\text { Sebagian } \\
\text { kecil } \\
\text { Sebagian } \\
\text { kecil } \\
\text { Sebagian } \\
\text { kecil } \\
\text { Sebagian } \\
\text { kecil }\end{array}$ \\
\hline
\end{tabular}


EduMa Vol. 5 No. 1 Juli 2016

ISSN $2086-3918$

\begin{tabular}{|c|c|c|c|c|c|c|}
\hline \multirow[t]{2}{*}{ Indikator } & $\begin{array}{l}\text { No. } \\
\text { Ite } \\
\mathrm{m}\end{array}$ & $\begin{array}{l}\text { Sk } \\
\text { or }\end{array}$ & $\mathrm{F}$ & $\mathrm{N}$ & $\begin{aligned} & P \\
= & \frac{F}{N} \times 100\end{aligned}$ & $\begin{array}{c}\text { Interpret } \\
\text { asi }\end{array}$ \\
\hline & & & & $\begin{array}{l}3 \\
7\end{array}$ & & $\begin{array}{c}\text { Hampir } \\
\text { setengah } \\
\text { nya }\end{array}$ \\
\hline \multirow[t]{2}{*}{$\begin{array}{l}\text { Siswadapatmengerjakanperhitung } \\
\text { yang } \\
\text { berkaitandengankelilingdanluasjaja } \\
\text { rgenjang }\end{array}$} & 9 & $\begin{array}{l}1 \\
2 \\
3 \\
4 \\
5 \\
6\end{array}$ & $\begin{array}{l}7 \\
2 \\
1 \\
3 \\
6 \\
1 \\
8\end{array}$ & $\begin{array}{l}3 \\
7 \\
3 \\
7 \\
3 \\
7 \\
3 \\
7 \\
3 \\
7 \\
3 \\
7\end{array}$ & $\begin{array}{c}18,9 \\
5,4 \\
2,7 \\
8,1 \\
16,2 \\
48,6\end{array}$ & $\begin{array}{c}\text { Sebagian } \\
\text { kecil } \\
\text { Sebagian } \\
\text { kecil } \\
\text { Sebagian } \\
\text { kecil } \\
\text { Sebagian } \\
\text { kecil } \\
\text { Sebagian } \\
\text { kecil } \\
\text { Hampir } \\
\text { setengah } \\
\text { nya }\end{array}$ \\
\hline & 10 & $\begin{array}{l}0 \\
1 \\
2 \\
3 \\
4 \\
5 \\
6\end{array}$ & $\begin{array}{l}4 \\
3 \\
4 \\
7 \\
2\end{array}$ & $\begin{array}{l}3 \\
7 \\
3 \\
7 \\
3 \\
7 \\
3 \\
7 \\
3 \\
7\end{array}$ & $\begin{array}{c}10,8 \\
35,1 \\
\\
10,8 \\
8,1 \\
10,8 \\
18,9 \\
5,4\end{array}$ & $\begin{array}{c}\text { Sebagian } \\
\text { kecil } \\
\text { Hampir } \\
\text { setengah } \\
\text { nya } \\
\text { Sebagian } \\
\text { kecil } \\
\text { Sebagian } \\
\text { kecil } \\
\text { Sebagian } \\
\text { kecil } \\
\text { Sebagian } \\
\text { kecil } \\
\text { Sebagian } \\
\text { kecil }\end{array}$ \\
\hline
\end{tabular}

Perhitungan uji normalitas ini dilakukan dengan menggunakan programSPSS versi 16 . Hasil perhitungan dapat kita lihat pada tabel uji Shapiro-Wilk di bawah ini:

Tabel 9

Tests of Normality

\begin{tabular}{|l|c|c|c|}
\hline & \multicolumn{3}{|c|}{ Shapiro-Wilk } \\
\cline { 2 - 4 } & Statistic & Df & Sig. \\
\hline Unstandardized Residual & .976 & 37 & .608 \\
\hline
\end{tabular}

a. Lilliefors Significance Correction

Berdasarkan tabel di atas, pengujian normalitas Error (residu) dengan uji ShapiroWilk pada kolom Unstandardized Residual didapat nilai sig. 0.446 dengan taraf signifikansi $\alpha=0,05$. Dengan demikian $p$ valueShapiro-Wilk (nilai p) > 0,05, yakni 0,608>0,05 maka artinya error berdistribusi normal atau data tersebut semuanya berdistribusi normal.

Hasil yang diperoleh dari hasil SPSS versi 16 dengan menggunakan uji Levene Test, dapat dilihat pada tabel di bawah ini: 
Tabel 8

Test of Homogeneity of Variances

\begin{tabular}{|c|c|c|c|}
\hline Levene Statistic & $\mathrm{df} 1$ & $\mathrm{df} 2$ & Sig. \\
\hline 2.062 & 9 & 14 & .109 \\
\hline
\end{tabular}

Berdasarkan tabel hasil uji homogenitas dengan menggunakan Levene Test dapat diketahui bahwa nilai Sig. sampel yaitu 0,109 dan berada di atas 0,05. Karena nilai sig 0,109>0,05, maka dengan demikian dapat disimpulkan bahwa data tersebut berdistribusi homogen.

Berdasarkan hasil perhitungan dengan menggunakan program SPSS versi 16 diperoleh data seperti pada tabel di bawah ini:

Tabel 9

Model Summaryb

\begin{tabular}{|c|c|c|c|c|}
\hline Model & $\mathrm{R}$ & $\mathrm{R}$ Square & $\begin{array}{c}\text { Adjusted R } \\
\text { Square }\end{array}$ & $\begin{array}{c}\text { Std. Error of the } \\
\text { Estimate }\end{array}$ \\
\hline 1 & $.587 \mathrm{a}$ & .345 & .326 & 13.8777 \\
\hline
\end{tabular}

a. Predictors: (Constant), Skor Total Pemahaman Konsep Geometri

b. Dependent Variable: Skor Total Kemampuan Siswa dalam Menyelesaikan Soal-soal Bidang Datar

Dari hasil analisis korelasi sederhana (r) didapat korelasi antara pemahaman konsep geometri dengan kemampuan siswa dalam menyelesaikan soal-soal bidang datar (r) adalah 0,587. Dilihat dalam tabel nilai koefisien korelasi tabel 3.5, nilai 0,40-0,59 menunjukkan interpretasi cukup. Hal ini menunjukkan bahwa antara pemahaman konsep geometri dengan kemampuan siswa dalam menyelesaikan soal-soal bidang datar mempunyai hubungan yang cukup.
Analisis regresi dapat dilakukan dengan uji regresi linier satu variabel independent. Persamaan regresi digunakan untuk melakukan prediksi seberapa tinggi nilai variabel dependent berdasarkan nilai variabel independent. Dengan menggunakan bantuan program SPSS versi 16 diperoleh hasil sebagai berikut:

Tabel 10

Coefficients $^{\mathrm{a}}$

\begin{tabular}{|c|c|c|c|c|c|}
\hline \multirow{2}{*}{ Model } & \multicolumn{2}{|c|}{$\begin{array}{c}\text { Unstandardized } \\
\text { Coefficients }\end{array}$} & $\begin{array}{c}\text { Standardized } \\
\text { Coefficients }\end{array}$ & & \\
\cline { 2 - 5 } & $\mathrm{B}$ & $\begin{array}{c}\text { Std. } \\
\text { Error }\end{array}$ & Beta & $\mathrm{t}$ & Sig. \\
\hline 1 & & & & 2.926 & .006 \\
\hline $\begin{array}{l}\text { (Constant) } \\
\begin{array}{l}\text { Pemahaman } \\
\text { Konsep } \\
\text { Geometri }\end{array}\end{array}$ & .612 & .143 & .587 & 4.294 & .000 \\
\hline
\end{tabular}

a. Dependent Variable: Kemampuan Siswa dalam Menyelesaikan Soal-soal Bidang Datar

Berdasarkan tabel menunjukkan regresi yang dicari nilai sig. dari konstanta $=$ $0.000<0,05$ dan nilai sig. variabel $\mathrm{X}$ nya sebesar $0.000<0,05$. Dengan demikian persamaan regresi untuk kedua variabel tersebut adalah:
$\widehat{Y}=\alpha+b X$

$\widehat{Y}=27,785+0,612 X$

$\widehat{\mathrm{Y}}=$ Kemampuan siswa dalam menyelesaikan soal-soal bidang datar 


$$
\mathrm{X}=\text { Pemahaman konsep geometri }
$$

Arti persamaan ini sebagai berikut:

1) Konstanta sebesar 27,785; artinya jika pemahaman konsep geometri (X) nilainya adalah sebesar 0 kali, maka kemampuan siswa dalam menyelesaikan soal-soal bidang datar $(\widehat{Y})$ nilainya sebesar 27,785.

2) Koefisien regresi variabel pemahaman konsep geometri (X) nilainya adalah 0,612; artinya jika pemahaman konsep geometri mengalami peningkatan sebesar satu kali, maka kemampuan siswa dalam menyelesaikan soal-soal bidang datar $(\widehat{Y})$ akan mengalami peningkatan sebesar 0,612 . Koefisien bernilai positif artinya terjadi hubungan positif antara pemahaman konsep geometri dengan kemampuan siswa dalam menyelesaikan soal-soal bidang datar, semakin tinggi pemahaman konsep geometri maka semakin meningkat kemampuan siswa dalan menyelesaikan soa-soal bidang datar.

Ini berarti terdapat pengaruh yang signifikan antara pemahaman konsep geometri terhadap kemampuan siswa dalam menyelesaikan soal-soal bidang datar.

Uji hipotesis dilakukan untuk mengetahui ada tidaknya pengaruh dari Pemahaman Konsep Geometri terhadap Kemampuan Siswa Dalam Menyelesaikan Soal-soal Bidang Datar. Diasumsikan bahwa $H_{o}$ adalah tidak ada pengaruh Pemahaman Konsep Geometri dan $H_{a}$ adalah adanya pengaruh positif yang signifikan dari Pemahaman Konsep Geometri. Dengan menggunakan bantuan SPSS versi 16 didapat output sebagai berikut:

Tabel 11

Coefficients $^{\mathrm{a}}$

\begin{tabular}{|c|c|c|c|c|c|}
\hline \multirow[b]{2}{*}{ Model } & \multicolumn{2}{|c|}{$\begin{array}{l}\text { Unstandardize } \\
\text { d Coefficients }\end{array}$} & \multirow{2}{*}{$\begin{array}{c}\text { Standardized } \\
\text { Coefficients } \\
\text { Beta }\end{array}$} & \multirow[b]{2}{*}{$\mathrm{t}$} & \multirow[b]{2}{*}{ Sig. } \\
\hline & B & $\begin{array}{l}\text { Std. } \\
\text { Error }\end{array}$ & & & \\
\hline 1 (Constant) & 27.785 & 9.497 & & 2.926 & .006 \\
\hline $\begin{array}{l}\text { Pemahaman } \\
\text { Konsep } \\
\text { Geometri }\end{array}$ & .612 & .143 & .587 & 4.294 & .000 \\
\hline
\end{tabular}

a. Dependent Variable: Kemampuan Siswa dalam Menyelesaikan

Soal-soal Bidang Datar

Nilai $t$ hitung pada variabel pemahaman konsep geometri adalah 4,294. Pada derajat bebas $(\mathrm{df})=\mathrm{N}-2=37-2=35$, nilai $t$ tabel pada taraf kepercayaan 95\% (signifikansi 5\%) adalah 2,030. Dari keterangan di atas dapat kita simpulkan bahwa $t_{\text {hitung }}>t_{\text {tabel }}(4,294>$ 2,030) maka $H_{o}$ ditolak, artinya terdapat pengaruh antara pemahaman konsep geometri terhadap kemampuan siswa dalam menyelesaikan soal-soal bidang datar.

\section{PEMBAHASAN}

Hasil analisis persamaan regresi untuk kedua variabel tersebut menunjukan persamaan $\widehat{Y}=27,785+0,612 X$. Persamaan tersebut mengandung arti bahwa jika tanpa pemahaman konsep geometri maka kemampuan siswa dalam menyelesaikan soal-soal bidang datar sebesar 27,785.
Koefisien regresi sebesar 0,612 menyatakan bahwa jika pemahaman konsep geometri mengalami peningkatan sebesar satu kali, maka kemampuan siswa dalam menyelesaikan soal-soal bidang datar $(\widehat{Y})$ akan mengalami peningkatan sebesar 0,612 , sedangkan nilai konstanta sebesar 27,785 menunjukan bahwa jika pemahaman konsep geometri (X) nilainya adalah sebesar 0 kali, maka kemampuan siswa dalam menyelesaikan soal-soal bidang datar $(\widehat{Y})$ nilainya sebesar 27,785 .

Berdasarkan hasil analisis regresi, pemahaman konsep geometri merupakan salah satu faktor penunjang kemampuan siswa dalam menyelesaikan soal-soal bidang datar. Siswa yang menguasai pemahaman konsep geometri dengan baik cenderung 
lebih mahir dalam menyelesaikan soalsoal bidang datar yang diberikan oleh guru. Namun, siswa yang kurang pemahaman konsep geometri cenderung agak kesulitan dalam menyelesaikan soal-soal bidang datar yang diberikan oleh guru.

Pernyataan tersebut sama dengan yang dinyatakan oleh Ausabel sebagaimana dikutip oleh Herman Hudojo, seorang psikolog yang berpendapat bahwa pengetahuan baru yang dipelajari bergantung kepada pengetahuan yang telah dimiliki seseorang. Dalam belajar matematika, apabila konsep A dan konsep B mendasari konsep C, maka konsep $\mathrm{C}$ tidak mungkin dipelajari sebelum konsep A dan konsep B dipelajari terlebih dahulu. ${ }^{1}$

Hal ini menunjukkan bahwa konsep dasar matematika merupakan pengetahuan dan kemampuan dasar yang harus dikuasai terlebih dahulu sebelum mempelajari materi selanjutnya. Pernyataan tersebut mengandung arti bahwa semakin tinggi siswa dapat menguasai konsep dasar matematika dengan baik, maka siswa akan cenderung lebih mahir dalam menyelesaikan soal-soal bidang datar dengan ditunjang oleh pemahaman konsep geometri.

Hasil analisis regresi memiliki nilai koefisien determinasi (R) sebesar $34,4569 \%$ maka dapat diartikan bahwa variabel pemahaman konsep geometri memberikan kontribusi dalam meningkatkan kemampuan siswa dalam menyelesaikan soal-soal bidang datar sebesar $34,4569 \%$ dan sisanya $65,5431 \%$ ditentukan oleh variabel lain.

Dari hasil analisis korelasi sederhana (r) didapat korelasi antara pemahaman konsep geometri dengan kemampuan siswa dalam menyelesaikan soal-soal bidang datar (r) adalah 0,587. Dilihat dalam tabel nilai koefisien korelasi tabel 3.5, nilai 0,40-0,59 menunjukkan interpretasi cukup. Hal ini menunjukkan bahwa antara pemahaman konsep geometri dengan kemampuan siswa dalam menyelesaikan soal-soal bidang datar mempunyai hubungan yang cukup.

Nilai t hitung pada variabel pemahaman konsep geometri adalah 4,294. Pada derajat bebas $(\mathrm{df})=\mathrm{N}-2=37-2=35$, nilai t tabel pada taraf kepercayaan 95\% (signifikansi 5\%) adalah 2,030. Dari keterangan di atas dapat kita simpulkan bahwa $t_{\text {hitung }}>t_{\text {tabel }}(4,294>$ 2,030) maka $\mathrm{H}_{\mathrm{o}}$ ditolak, artinya terdapat pengaruh antara pemahaman konsep geometri terhadap kemampuan siswa dalam menyelesaikan soal-soal bidang datar.

\section{KESIMPULAN DAN SARAN}

\section{KESIMPULAN}

1. Pemahaman konsep geometri tentang segitiga dan segi empat pada siswa kelas VII SMP Negeri 1 Cidahu menunjukkan kategori sedang dengan skor rata-rata 64,676 .

2. Kemampuan siswa dalam menyelesaikan soal-soal bidang datar pada siswa kelas VII SMP Negeri 1 Cidahu menunjukkan kategori sedang dengan skor rata-rata 67,378 .

3. Koefisien regresi sebesar 0,612 menyatakan bahwa jika pemahaman konsep geometri mengalami peningkatan sebesar satu kali, maka kemampuan siswa dalam menyelesaikan soal-soal bidang datar $(\widehat{Y})$ akan mengalami peningkatan sebesar 0,612, sedangkan nilai konstanta sebesar 27,785 menunjukan bahwa jika pemahaman konsep geometri (X) nilainya adalah sebesar 0 kali, maka kemampuan siswa dalam menyelesaikan soal-soal bidang datar ( $(\widehat{Y})$ nilainya sebesar 27,785. Koefisien korelasi (r) sebesar 0,587 dan koefisien determinasi (R) sebesar 0,345 , sejalan dengan ketentuan nilai koefisien korelasi pada tabel $3.5 \quad(0,40-0,59)$ nilai tersebut termasuk ke dalam interpretasi cukup.

\section{SARAN}

1. Metode yang dipilih guru sebaiknya kegiatan pembelajaran yang menekan pada pemahaman konsep dan analitis untuk mencari dan menemukan sendiri jawaban dari suatu masalah. Guru hanya berperan sebagai fasilitator yang menciptakan proses belajar secara aktif, kreatif dan menyenangkan

2. Siswa harus belajar mengolah dan mengembangkan pemahaman konsep dengan baik, belajar aktif, selalu semangat, kreatif dan percaya diri

3. Penilitian selanjutnya hendaknya menggunakan populasi dan sampel 
yang lebih banyak serta pemilihan tempat penelitian yang lebih kompetitif demi kelancaran dan manfaat penelitian selanjutnya

\section{DAFTAR PUSTAKA}

Sugiyono. 2009. Statistika Untuk Penelitian. Bandung: Alfabeta

Toto Syatori Nasehuddien. 2011. Metodologi Penelitian Sebuah Pengantar. Cirebon: Nurjati Press,

Turmudi dalam http://digilib.unimed.ac.id/public/UNIMEDUndergraduate-22149-BAB\%20I.pdf. Diunduh: Sabtu, 31 Agustus 2013 pukul 07.35 WIB.

Mulyono Abdurrahman dalam http://digilib.unimed.ac.id/public/UNIMEDUndergraduate-22149-BAB\%20I.Diunduh: Sabtu, 31 Agustus 2013 pukul 07.35 WIB

Hasan Munir. dkk. 2003. Penelusuran Tingkat Perkembangan Berfikir Model Van Hiele pada Siswa SD Kelas III, IV, dan V
Dalam Belajar Geometri. Banda Aceh: Universitas Syah Kuala, hal.2

Hamzah B. Uno. 2008. Model Pembelajaran Menciptakan Proses Belajar Mengajar Yang Kreatif Dan Efektif. Jakarta: Bumi Aksara

W.S. Winkel. 1996. Psikologi Pendidikan. Jakarta: Grasindo

Haryanto. 1997. Perencanaan Pengajaran. Jakarta: Rineka Cipta

Djoko Iswadi. 2001. Geometri Ruang. Universitas Negeri Yogyakarta: Jurusan Pendidikan Matematika

Fadjar Shadiq. 2009. Geometri Dimensi Dua dan Tiga (Diklat Guru Pengembangan Matematika SMK Jenjang Dasar tahun 2009). Yogyakarta: PPPPTK Matematika

Susanta B. 1996.Geometri yang Baru dan Berkembang. Yogyakarta: UGM

Sukmadinata, NanaSyaodih. 2004. Landasan Psikologi Proses Pendidikan. Bandung: Rosdakarya 